\title{
UCRL-TR-202477-APP-D-12A
}

LAW RENCE LIVERMORE N A TION A L LABORATORY

\section{Appendix D-12A Building 332C Waste Accumulation Area}

Dawn Chase

March 3, 2005 
This document was prepared as an account of work sponsored by an agency of the United States Government. Neither the United States Government nor the University of California nor any of their employees, makes any warranty, express or implied, or assumes any legal liability or responsibility for the accuracy, completeness, or usefulness of any information, apparatus, product, or process disclosed, or represents that its use would not infringe privately owned rights. Reference herein to any specific commercial product, process, or service by trade name, trademark, manufacturer, or otherwise, does not necessarily constitute or imply its endorsement, recommendation, or favoring by the United States Government or the University of California. The views and opinions of authors expressed herein do not necessarily state or reflect those of the United States Government or the University of California, and shall not be used for advertising or product endorsement purposes.

This work was performed under the auspices of the U.S. Department of Energy by University of California, Lawrence Livermore National Laboratory under Contract W-7405-Eng-48. 


\section{APPENDIX D-12A}

\section{BUILDING 332C WASTE ACCUMULATION AREA}


UCRL-TR-202477-APP-D-12A 


\section{APPENDIX D-12A \\ BUILDING 332C WASTE ACCUMULATION AREA}

\section{Contents}

\begin{tabular}{|c|c|}
\hline D1.1 & General Information. \\
\hline 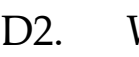 & WAA DESCRIPTION ........ \\
\hline D2.1 & General Information.. \\
\hline $\mathrm{D} 2.2$ & Physical Description... \\
\hline D2.3 & 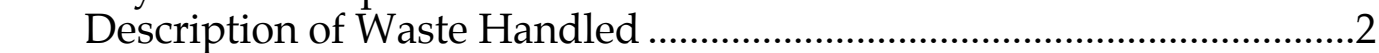 \\
\hline D3. & 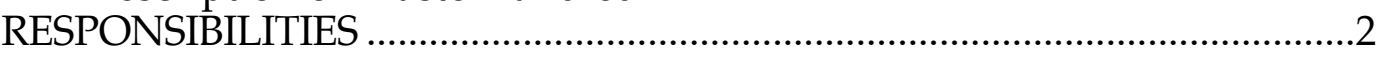 \\
\hline D4. & EMERGENCY EQUIPMENT. \\
\hline D4.1 & Emergency Equipment Available at the WAA ………………………............5 \\
\hline D4.2 & 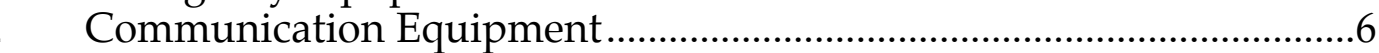 \\
\hline
\end{tabular}

\section{List of Figures}

Figure D-1. Location of the Building 332C WAA at LLNL Main Site ..................3

Figure D-2. The Building 332C WAA ……………..............................................

Figure D-3. The Building 332C WAA Evacuation Route........................................

\section{List of Tables}

Table D-1. Typical Wastes Stored in Building 332C WAA......................................5

Table D-2. Program Contacts and ES\&H Team 1 Contacts....................................5

Table D-3. Spill Kit Supplies ...................................................................................6

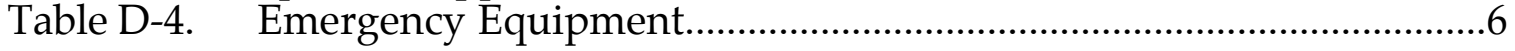


UCRL-TR-202477-APP-D-12A 


\section{APPENDIX D-12A \\ BUILDING 332C WASTE ACCUMULATION AREA}

\section{D1. INTRODUCTION}

This appendix is designed to provide information specific to the Building 332C Waste Accumulation Area (B-332C WAA), a waste storage area. This appendix is not designed to be used as a sole source of information. All general information that is not specific to the B-332C WAA is included in the Contingency Plan for Waste Accumulation Areas, dated July 2004, and should be referenced.

\section{D1.1 General Information}

\begin{tabular}{|l|l|}
\hline Facility Name & Building 332C Waste Accumulation Area \\
\hline Department/Program & Defense and Nuclear Technologies \\
\hline Site Operator & Regents, University of California \\
& Lawrence Livermore National Laboratory \\
& P.O. Box 808 \\
Livermore, CA 94551
\end{tabular}




\section{D2. WAA DESCRIPTION}

\section{D2.1 General Information}

The B-332C WAA is located in the southwest quadrant of the LLNL Main Site (see Figure D-1), in Building 332, Room 1330. Hazardous and mixed wastes may be stored at the B-332C WAA for 90 days or less, until transferred to the appropriate Radioactive and Hazardous Waste Management (RHWM) facility or other permitted treatment, storage or disposal facility (TSDF). Radioactive waste may also be stored at the WAA. The design storage capacity of this WAA is 2,200 gallons.

\section{D2.2 Physical Description}

The B-332C WAA is inside B-332 in Room 1330. Room 1330 is a $16^{\prime} \times 19^{\prime}$ room that is designated as a WAA in its entirety. The room is locked which prevents access from unauthorized personnel.

A telephone is located on the west wall inside the WAA (see Figure D-2). A fire extinguisher is located in the hall, south of the WAA, between Rooms 1332 and 1334. Spill kit supplies and personal protective equipment described in Section D4 are stored in the hallway as identified in Figure D-2. An emergency shower/eyewash is located north of Room 1330, in the hall next to Room 1338.

\section{D2.3 Description of Waste Handled}

Table D-1 lists the waste types typically stored in the B-332C WAA. This list is intended to alert personnel to the potential hazards in the WAA, but each situation should be evaluated based on the actual materials involved. Waste may be stored in DOT-approved containers ranging from 5-gallon cans to 55-gallon drums. Standard waste boxes (SWB) may also be stored in the WAA.

\section{D3. RESPONSIBILITIES}

The WAA Coordinator, WAA Operator, ES\&H Team 1 Leader, Environmental Operations Group (EOG) Analyst, RHWM Technician, and ES\&H Technician are responsible for providing information and assistance in the event of an emergency. ES\&H Team 1 is the support team for the B-332C WAA. If additional support members are needed, the ES\&H Team 1 Leader or EOG Analyst will notify those members. Program contacts and ES\&H Team 1 contacts are listed in Table D-2. 


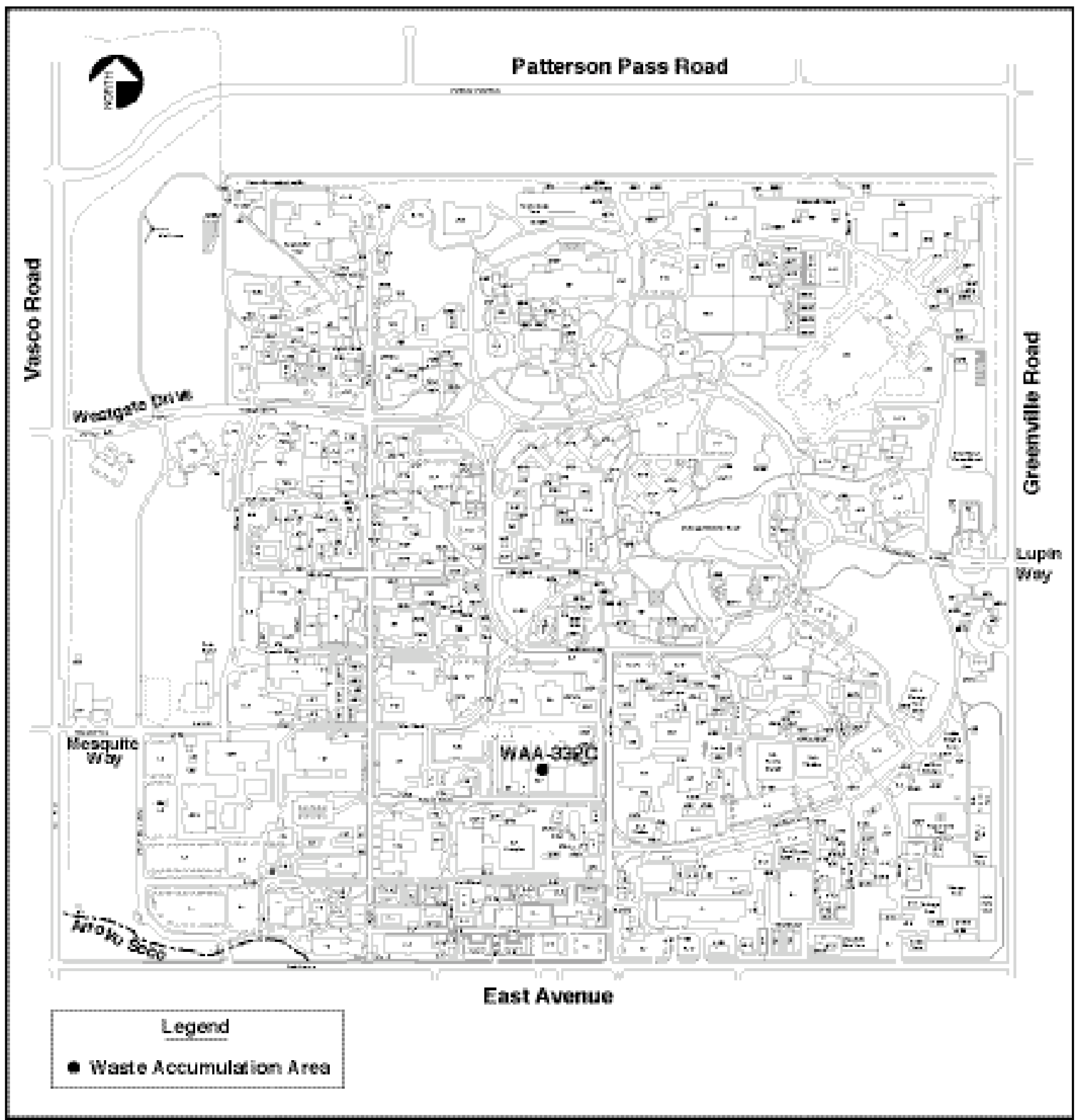

Figure D-1. Location of the Building 332C WAA at LLNL Main Site 


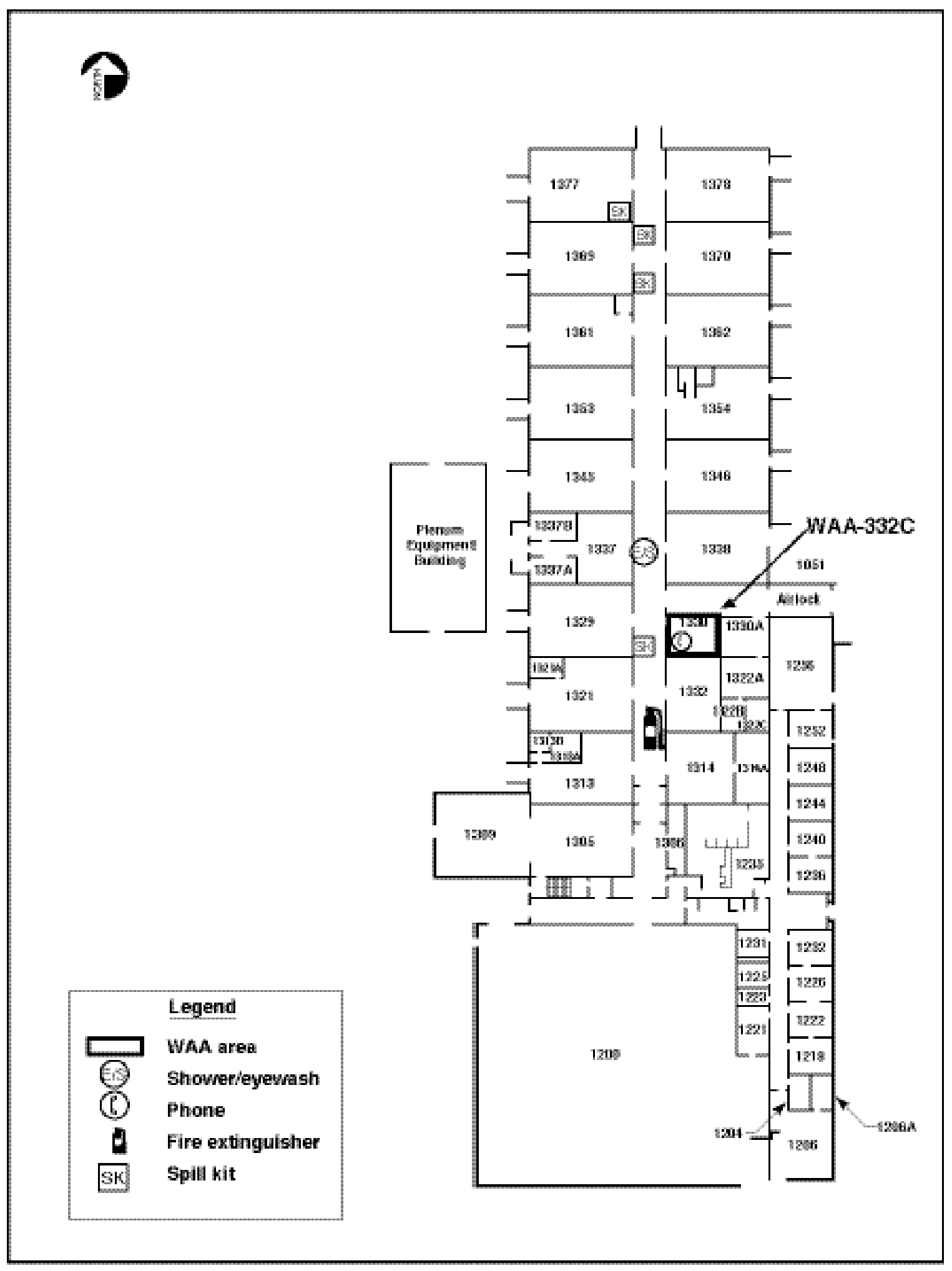

Figure D-2. The Building 332C WAA 
Table D-1. Typical Wastes Stored in Building 332C WAA

Asbestos

Equipment with radioactive or mixed contamination

Laboratory waste (solidified aqueous and organic solutions)

Mixed laboratory trash (paper and plastic contaminated with metals and radioactivity)

Table D-2. Program Contacts and ES\&H Team 1 Contacts

\begin{tabular}{llcl}
\hline Contact & Name & Phone & Pager \\
\hline WAA Coordinator & Dave Hiland & $423-3163$ & 61056 \\
WAA Operator & Jeff Wilson & $424-4189$ & 63000 \\
ES\&H Team 1 Leader & Jim Mecozzi & $423-3762$ & 04024 \\
EOG Analyst & Dawn Chase & $423-9136$ & 04257 \\
RHWM Technician & Richard Clark & $423-4076$ & 01265 \\
ES\&H Technician & Bill Talbot & $423-3402$ & 05323 \\
\hline
\end{tabular}

In an emergency, immediately notify the Alameda County Regional Emergency Communications Center at extension 911 or dial (925) 447-6880 if calling from off-site, cellular phone, or pay phone. If paging from off-site, cellular phone, or pay phone, dial (925) 423-7705 and pager number.

\section{D4. EMERGENCY EQUIPMENT}

\section{D4.1 Emergency Equipment Available at the WAA}

The B-332C WAA has spill kit supplies, a fire extinguisher, personal protective equipment, and decontamination equipment. Material Safety Data Sheets (MSDSs) are available at or near the WAA; they provide general information on chemical hazards and personal protective equipment needed to manage chemicals. MSDSs may indicate the emergency actions to be taken if personnel come in contact with the chemicals. The location, type, and quantity of spill kit supplies required for the operation of the B-332C WAA are listed in Table D-3. Other emergency equipment required in this area is listed in Table D-4. The location of emergency equipment is shown in Figure D-2. 
Table D-3. Spill Kit Supplies

\begin{tabular}{lcll}
\hline Supplies & Quantity & Use & Location \\
\hline Polyethylene bags & 2 each & $\begin{array}{l}\text { Line drums and contain contaminated } \\
\text { absorbent or other solid waste. }\end{array}$ & $\begin{array}{l}\text { Hallway } \\
\text { adjacent to } \\
\text { Room 1369 }\end{array}$ \\
\hline Mop (antistatic) & 1 each & $\begin{array}{l}\text { Sweep absorbent material for } \\
\text { placement in waste containers. }\end{array}$ & Inside WAA \\
\hline $\begin{array}{l}\text { Gloves-neoprene or } \\
\text { nitrile }\end{array}$ & 5 pairs & $\begin{array}{l}\text { See Appendix A ("Personal } \\
\text { Protective Equipment”) in the } \\
\text { Contingency Plan for Waste } \\
\text { Accumulation Areas, July 2004. }\end{array}$ & $\begin{array}{l}\text { Spill kit in } \\
\text { hallway } \\
\text { adjacent to } \\
\text { Room 1369 }\end{array}$ \\
\hline Tape-2-in. duct & 1 roll & $\begin{array}{l}\text { Seal protective suits, gloves, and } \\
\text { containers. }\end{array}$ & $\begin{array}{l}\text { Spill kit in } \\
\text { hallway } \\
\text { adjacent to } \\
\text { Room 1369 }\end{array}$ \\
\hline
\end{tabular}

Table D-4. Emergency Equipment

\begin{tabular}{llll}
\hline Equipment & Quantity & Use & Location \\
\hline Eyewash & 1 each & Flush eyes for 15 min. & $\begin{array}{l}\text { South of WAA } \\
\text { in hallway } \\
\text { near Room 1362 }\end{array}$ \\
\hline Deluge shower & 1 each & Flush exposed area for 15 min. & $\begin{array}{l}\text { South of WAA } \\
\text { in hallway } \\
\text { near Room 1362 }\end{array}$ \\
\hline $\begin{array}{l}\text { Type ABC fire } \\
\text { extinguisher }\end{array}$ & 2 each & $\begin{array}{l}\text { Extinguish or control small electrical } \\
\text { or flammable liquids fires. LLNL } \\
\text { Fire Department must be called if a } \\
\text { fire occurs. }\end{array}$ & $\begin{array}{l}\text { Hallway near } \\
\text { Room 1378 }\end{array}$ \\
\hline
\end{tabular}

\section{D4.2 Communication Equipment}

A telephone is located on the west wall of Room 1330 in B-332. Other rooms and buildings in the area are also equipped with telephones.

\section{D5. EVACUATION ROUTES AND ASSEMBLY POINT}

Evacuation of the B-332C WAA is through the west doors. See Figure D-3 for the location of the evacuation routes and assembly point. After evacuation, personnel should gather at the assembly point located east of Building 335 (see Figure D-3). 


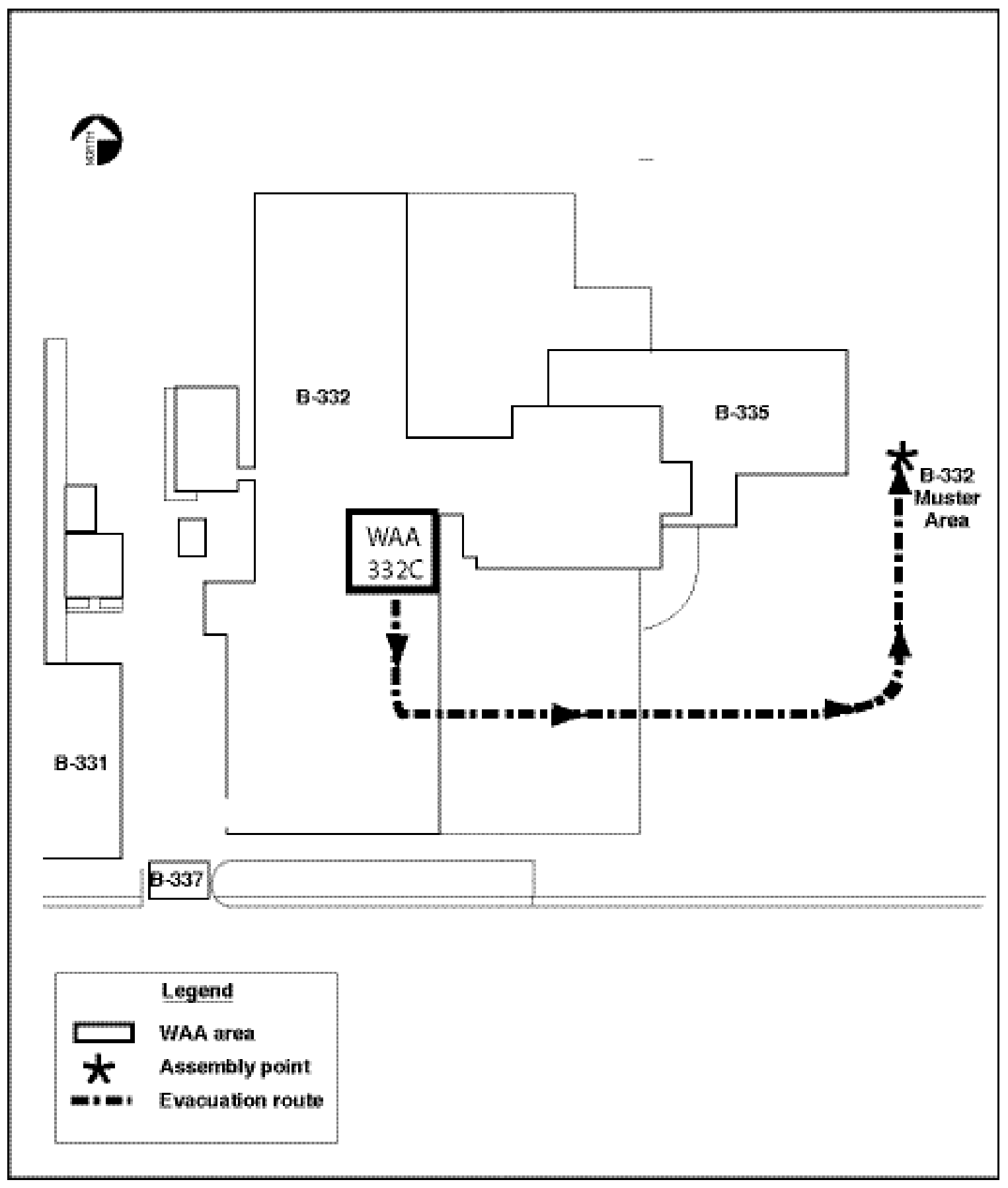

Figure D-3. The Building 332C WAA Evacuation Route 
UCRL-TR-202477-APP-D-12A 